Furthermore, the close association between fall in disease activity and rise in serum PAG concentrations in eight of the 14 patients in this study gives added credence to the highly significant though relatively low negative coefficient between these two variables. It must be emphasised that most clinical methods for assessing disease activity in rheumatoid arthritis are to some extent subjective and can be affected by, for example, variation in the pain threshold of individual patients. Hence to obtain even a low correlation coefficient between a relatively subjective value and a highly accurate measurement of a serum substance is quite remarkable.

It is also relevant to draw attention to our finding that there was no correlation between disease activity and another pregnancy associated protein, $\mathrm{SP}_{1}$, which unlike PAG has not been shown to have any immunosuppressive properties in vitro. There may, however, be other factors-for example, hormones and other pregnancy associated proteins not measured so far which could be affecting disease activity in these patients. Nevertheless, the preliminary results of this study provide some evidence for an association between serum PAG concentrations and the course of rheumatoid disease activity during pregnancy.

We thank Drs P Blower, B Bresnihan, N Cardoe, J Carty, A Crisp, J Cuddigan, T Dilke, R Grahame, W Grant, J Halsey, E Kauffmann, W Mace, A Nichols, and J Wotjulewski for making this study possible, either by allowing us access to their patients or by carrying out assess- ments for us. This project was supported by the Arthritis and Rheumatism Council.

Requests for reprints should be sent to Professor Gabriel S Panayi.

\section{References}

${ }^{1}$ Hench PS. The ameliorating effect of pregnancy on chronic atrophic (infectious rheumatoid) arthritis, fibrositis, and intermittent hydrarthrosis. Mayo Clin Proc 1938;13:161-8.

2 Smith WD, West HF. Pregnancy and rheumatoid arthritis. Acta Rheumatologica Scandinavica 1960;6:189-201.

${ }^{3}$ Denman AM. Pregnancy and immunological disorders. Br Med $\mathcal{F} 1982$; 284:999-1000.

4 Thomson AW, Horne CHW. Biological and clinical significance of pregnancy-associated $\alpha_{2}$-glycoprotein $\left(\alpha_{2}-\mathrm{PAG}\right)$-a review. Invest Cell Pathol 1980;3:295-309.

${ }^{5}$ Persellin RH. The effect of pregnancy on rheumatoid arthritis. Bull Rheum Dis $1977 ; 27: 922-6$

${ }^{6}$ Ropes MW, Bennet GA, Cobb S, Jacox R, Jessar RA. Diagnostic criteria for rheumatoid arthritis. Ann Rheum Dis 1959;18:49-51.

7 Camp AV. An articular index for the assessment of rheumatoid arthritis. Orthopaedics (Oxford) 1971;4:39-45.

${ }^{8}$ Mancini G, Carbonara AO, Heremans JF. Immunochemical quantitation of antigens by single radial immunodiffusion. Immunochemistry $1965 ; 2$ 235-54.

${ }^{9}$ Faith A, Pontesilli O, Unger A, Panayi GS, Johns P. ELISA assays of IgM and IgG rheumatoid factors. $\mathcal{F}$ Immunol Methods (in press).

\title{
Erythrocyte ferritin content in idiopathic haemochromatosis and alcoholic liver disease with iron overload
}

\author{
MARTIN B VAN DER WEYDEN, HUBERT FONG, HATEM H SALEM, ROBERT G BATEY, \\ FRANK J DUDLEY
}

\begin{abstract}
The erythrocyte ferritin content was measured in patients with either idiopathic haemochromatosis or alcoholic liver disease and iron overload to define its value as a marker for an excess of tissue iron. The mean erythrocyte ferritin content in patients with untreated idiopathic haemochromatosis was increased 60-fold and fell with phlebotomy. After phlebotomy many patients had an increased red cell ferritin content despite normal serum ferritin concentrations. That this reflected persistent iron overload with inadequate phlebotomy was suggested by the higher serum iron concentrations, percentage transferrin saturation, and urinary excretion of iron after administration of desferrioxamine, together with a lower annual iron loss by phlebotomy in this group compared
\end{abstract}

\footnotetext{
Monash University Department of Medicine, Alfred Hospital, Prahran, 3181, Victoria, Australia

MARTIN B VAN DER WEYDEN, MD, FRACP, clinical associate professor HATEM H SALEM, MRCP, lecturer

Department of Clinical Biochemistry, Alfred Hospital

HUBERT FONG, MSC, scientific officer

Drug and Alcohol and Gastroenterology Units, Westmead Medical Centre, Westmead, 2145, New South Wales, Australia

ROBERT G BATEY, MB, FRACP, director

Gastroenterology Service, Alfred Hospital

FRANK J DUDLEY, MD, FRACP, director
}

with patients with treated disease and normal red cell ferritin content. The mean erythrocyte ferritin content in patients with alcoholic liver disease and iron overload was increased only sevenfold, and the ratio of erythrocyte to serum ferritin clearly discriminated these patients from those with idiopathic haemochromatosis.

The determination of erythrocyte ferritin content is a useful non-invasive test for diagnosing idiopathic haemochromatosis, monitoring the effect of phlebotomy in this disorder, and distinguishing patients with this disorder from those with alcoholic liver disease with iron overload.

\section{Introduction}

Idiopathic haemochromatosis is an inherited disorder of iron metabolism characterised by excessive absorption of iron leading to iron overload and deposition of iron in tissue, particularly in liver parenchymal cells. In patients with symptomatic disease this excess of iron is accompanied by increases in serum iron and ferritin concentrations, the percentage saturation of transferrin, and urinary excretion of iron after administration of desferrioxamine. ${ }^{1}$ Whether these variables accurately identify the precirrhotic phase of the disease is uncertain, as a raised serum iron concentration and increased percentage saturation of transferrin occur in up to one third of normal relatives of patients with the disease, ${ }^{2}$ and normal serum ferritin concentrations accompany iron overload in some instances. ${ }^{23}$ Diagnostic problems also arise in alcoholics with raised iron variables, histological evidence 
of cirrhosis, and parenchymal iron overload when family studies do not show an abnormality in iron metabolism. These uncertainties have led to use of other markers to indicate idiopathic haemochromatosis.

The localisation of the gene for at least one form of idiopathic haemochromatosis to chromosome 6 near the HLA-A locus ${ }^{4} 5$ enabled the presence of HLA-A 3 antigen to be used to identify individuals at risk for the disease. ${ }^{4-6}$ Since the disease is manifested clinically by an excess of iron in tissue and since intracellular iron stimulates synthesis of ferritin ${ }^{7}$ we reasoned that the intracellular erythrocyte ferritin content might indicate this tissue iron excess. We explored this hypothesis by determining erythrocyte ferritin content in patients with untreated and treated idiopathic haemochromatosis and alcoholic patients with hepatic parenchymal iron excess and cirrhosis. assessment of the iron removed by phlebotomy $500 \mathrm{ml}$ whole blood was assumed to have an iron content of $0.25 \mathrm{~g}^{15}$ and results were expressed as the average number of grams of iron per year over the period of phlebotomy.

Erythrocyte ferritin content was assayed as previously described using hepatic ferritin radioimmunoassay. ${ }^{16}$ The range of erythrocyte ferritin was $0.004-0.047 \mathrm{fg}$ ferritin/cell in 32 normal subjects studied. ${ }^{16}$ For determination of the ratio of erythrocyte to serum ferritin red cell ferritin was expressed as $\mu \mathrm{g} / 10^{12}$ cells and serum ferritin as $\mu \mathrm{g} / \mathrm{l}$. Statistical analysis was done with Student's $t$ test.

\section{Results}

Erythrocyte ferritin content in patients with untreated idiopathic haemochromatosis or alcoholic liver disease with iron overload-Table I

TABLE I-Erythrocyte ferritin content and iron variables in patients with idiopathic haemochromatosis (group $A$ ) and alcoholic liver disease with iron overload (group $C$ ) (expressed as means $+1 S D)$

\begin{tabular}{|c|c|c|c|c|c|c|c|}
\hline & $\begin{array}{c}\text { Erythrocyte } \\
\text { ferritin } \\
\text { (fg/cell) }\end{array}$ & $\begin{array}{c}\text { Ratio of } \\
\text { erythrocyte: } \\
\text { serum ferritin }\end{array}$ & $\begin{array}{c}\text { Serum iron } \\
(\mu \mathrm{mol} / 1)\end{array}$ & 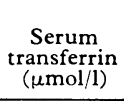 & $\begin{array}{l}\% \text { transferrin } \\
\text { saturation }\end{array}$ & $\begin{array}{c}\text { Serum } \\
\text { ferritin } \\
(\mu \mathrm{g} / 1)\end{array}$ & $\begin{array}{c}\text { Mean urinary iron } \\
\text { excretion after } \\
\text { desferrioxamine } \\
(\mu \mathrm{mol} / 24 \mathrm{~h})\end{array}$ \\
\hline $\begin{array}{l}\text { Group A }(n=8) \\
\text { Group C }(n=6)\end{array}$ & $\begin{array}{c}0.88 \pm 0.70^{\dagger} \\
0 \cdot 10=0.05 \\
p<0.05\end{array}$ & $\begin{array}{c}0.5 \div 0.3 \\
0.03: 0.04 \\
p<0.01\end{array}$ & $\begin{array}{l}39 \pm 7 \\
39 \pm 10 \\
\mathrm{NS}\end{array}$ & $\begin{array}{c:c}46 & 9 \\
52 & 16 \\
\text { NS }\end{array}$ & $\begin{array}{c}84 \pm 18 \\
76 \div 14 \\
\text { NS }\end{array}$ & $\begin{array}{c}2471 \pm 1780 \\
4281 \pm 4634 \\
\text { NS }\end{array}$ & $\begin{array}{r}215(\mathrm{n}=5) \\
64(\mathrm{n}=3)\end{array}$ \\
\hline
\end{tabular}

Conversion: SI to traditional units-Iron: $1 \mu \mathrm{mol} / 1 \approx 5.6 \mu \mathrm{g} / 100 \mathrm{ml}$.

TABLE II-Erythrocyte ferritin content and iron variables in patients with idiopathic haemochromatosis after phlebotomy (group B) (expressed as means $\perp 1 S D$ )

\begin{tabular}{|c|c|c|c|c|c|c|c|}
\hline & $\begin{array}{l}\text { Erythrocyte } \\
\text { ferritin } \\
\text { (fg/cell) }\end{array}$ & $\begin{array}{c}\text { Serum iron } \\
(\mu \mathrm{mol} / \mathrm{l})\end{array}$ & $\underset{\substack{\text { Seransferrin } \\
(\mu \mathrm{mol} / 1)}}{\text { Serum }}$ & $\begin{array}{l}\% \text { transferrin } \\
\text { saturation }\end{array}$ & $\begin{array}{l}\text { Serum } \\
\text { ferritin } \\
(\mu \mathrm{g} / \mathrm{l})\end{array}$ & $\begin{array}{c}\text { Urinary iron } \\
\text { excretion after } \\
\text { desferrioxamine } \\
(\mu \mathrm{mol} / 24 \mathrm{~h})\end{array}$ & $\begin{array}{l}\text { Annual iron loss } \\
\text { by phlebotomy } \\
(\mathrm{g})\end{array}$ \\
\hline Normal values & $<0.05$ & $<32$ & $<90$ & $<50$ & $<200$ & $<36$ & \\
\hline $\begin{array}{l}\text { Erythrocyte ferritin: } \\
\text { Raised }(n=16) \\
\text { Normal }(n=8)\end{array}$ & $\begin{array}{l:l}0.26 & 0.33 \\
0.02 & 0.01\end{array}$ & $\begin{array}{l}40 \pm 7 \\
23=12 \\
p<0.01\end{array}$ & $\begin{array}{l}63 \pm 9 \\
61 \pm 13 \\
\text { NS }\end{array}$ & $\begin{array}{l}64 \div 14 \\
39-23 \\
p<0.01\end{array}$ & $\begin{array}{c}132 \pm 78 \\
77 \div 78 \\
\text { NS }\end{array}$ & $\begin{array}{c}34 \pm 18(n=12) \\
14 \pm 2(n=5) \\
p<0.025\end{array}$ & $\begin{array}{l}2.8 \pm 2.3 \\
5 \cdot 1 \pm 2.9 \\
p<0.05\end{array}$ \\
\hline
\end{tabular}

Conversion: SI to traditional units-Iron: $1 \mu \mathrm{mol} / 1 \approx 5.6 \mu \mathrm{g} / 100 \mathrm{ml}$

\section{Patients and methods}

Patients were studied sequentially and included eight with untreated idiopathic haemochromatosis (group A) diagnosed according to defined criteria, ${ }^{8} 24$ with idiopathic haemochromatosis after phlebotomy (group B), and six with alcoholic liver disease and iron overload (group C). Group A comprised four women and four men with a mean age of 53 (range 30-77). Pertinent clinical findings included hepatomegaly in eight, glucose intolerance in two, and arthritis in one. Liver biopsy performed in all showed grades 3-4 of stainable parenchymal iron in all patients and micronodular cirrhosis in four. Group B comprised 19 men and five women with a mean age of 61 (range 35-79). Clinical findings before regular phlebotomy included hepatomegaly in all, glucose intolerance in 13, arthritis in nine, and cardiomyopathy in three. Liver biopsy performed in 19 showed grades 2-4 of stainable iron in all and micronodular cirrhosis in 16. Group C comprised six men with a mean age of 60 (range 45-67). All had hepatomegaly, erythrocytic macrocytosis (mean corpuscular volume $>100 \mathrm{fl}$ ) and raised serum aspartate aminotransferase activity $(-50 \mathrm{U} / \mathrm{l})$. Liver biopsy performed in five showed grades $2-4$ of stainable iron in all, together with micronodular cirrhosis in four.

Serum iron and transferrin concentrations were measured with standard techniques. ${ }^{9-11}$ Serum ferritin concentration was measured by hepatic ferritin radioimmunoassay. ${ }^{12}$ Liver biopsy sections were stained with haemotoxylin and eosin, a reticulin stain, and Perls' prussian blue stain for iron. The amount of stainable iron in hepatocytes was graded 0 to 4 ; grade 1 may be normal, but grades $2-4$ are abnormal. ${ }^{13}$ Patients received oral ascorbic acid $500 \mathrm{mg}$ daily for one week before urinary iron excretion was determined after administration of desferrioxamine. After an intramuscular injection of $0.5 \mathrm{~g}$ desferrioxamine 24 hour urinary iron excretion was estimated. ${ }^{14}$ For shows the erythrocyte ferritin content together with conventional iron variables in patients with untreated idiopathic haemochromatosis (group A) and those with alcoholic liver disease with iron overload (group C). The increased serum iron and ferritin concentrations and percentage saturation of transferrin were not significantly different between the two groups but the mean urinary iron excretion after administration of desferrioxamine in group $\mathrm{A}$ was roughly four times that in group $\mathrm{C}$. The mean erythrocyte ferritin content in the patients in group $\mathrm{A}$ was eight times that in those in group $\mathrm{C}$ and 60 times that in haematologically normal subjects. The figure shows the distribution of erythrocyte ferritin in both groups. Except for one patient with precirrhotic idiopathic haemochromatosis the erythrocyte ferritin content in patients in group A was considerably higher than that in patients in group B. Despite this overlap table I shows that the ratio of erythrocyte to serum ferritin clearly separated patients in the two groups.

Erythrocyte ferritin content in patients with treated idiopathic haemochromatosis - The erythrocyte ferritin content in two patients with idiopathic haemochromatosis sequentially followed up after diagnosis fell with phlebotomy (figure). Although all patients who had received treatment (presumed adequate) had normal or near normal serum ferritin concentrations, they fell arbitrarily into two groups with either normal or increased erythrocyte ferritin content (figure). Table II shows that patients with a normal red cell ferritin content had significantly lower serum iron concentration, percentage transferrin saturation, and urinary iron excretion after administration of desferrioxamine and roughly twice the annual iron loss with phlebotomy compared with patients with a raised red cell ferritin content. These findings suggest that a raised erythrocyte ferritin content identifies patients with idiopathic haemochromatosis requiring further vigorous phlebotomy. 


\section{Discussion}

Retrospective evaluation of phlebotomy in idiopathic haemochromatosis suggested that removal of iron improves survival and reduces morbidity, ${ }^{17}$ but in patients with alcoholic liver disease and iron overload life expectancy is not affected. ${ }^{18}$ Thus, for therapeutic reasons alone, distinguishing these two groups is necessary but may be difficult clinically. In patients with alcoholic liver disease subtle features such as peripheral neuropathy and cerebellar ataxia may be present together with lesser degrees of iron overload as judged by serum ferritin concentra-

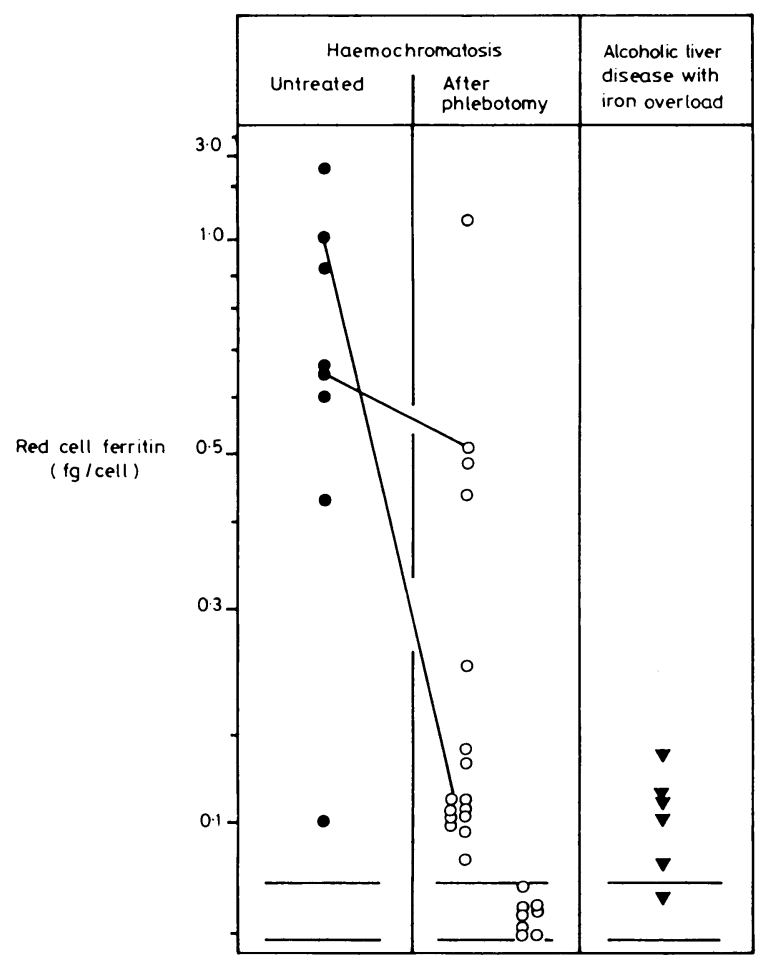

Distribution of erythrocyte ferritin content in patients with untreated $(\bullet)$ or treated $(O)$ idiopathic haemochromatosis and patients with alcoholic liver disease with iron overload $(\nabla)$ Horizontal bars indicate normal range.

tions, urinary iron excretion after administration of desferrioxamine, and liver iron content. ${ }^{8}$ As seen in this study, however, these indicators of tissue iron content may overlap considerably between the two diseases. Furthermore, these variables are unreliable when active hepatocellular necrosis is present. Since ferritin encapsulated within the red cell should not be influenced by the fluctuations in iron variables in active liver disease, it is not entirely surprising that the erythrocyte ferritin content and the ratio of erythrocyte to serum ferritin may be used to discriminate between patients with idiopathic haemochromatosis and those with alcoholic liver disease with iron excess.

Early diagnosis and vigorous phlebotomy are essential in the optimal management of idiopathic haemochromatosis; with established cirrhosis removal of iron does not prevent the subsequent development of malignant hepatoma, whereas adequate phlebotomy in the precirrhotic phase prevents most complications of the disease. ${ }^{1817}$ The definitive test for increased tissue iron is chemical estimation of hepatic iron concentration; apart from this invasive procedure, all other measurements of variables that indicate iron overload are indirect with recognised limitations.

In the present study patients with idiopathic haemochromatosis including four in the precirrhotic phase had an erythrocyte ferritin content on average 60 times that in normal subjects; phlebotomy decreased these raised values. In addition, erythrocyte ferritin content identified patients with the disease after phlebotomy, who despite normal serum ferritin concentrations had a raised red cell ferritin content. That this finding indicated persistent raised iron stores was suggested by the higher serum iron concentration, percentage transferrin saturation, and urinary iron excretion after administration of desferrioxamine and lower annual loss of iron by phlebotomy in this group compared with patients with idiopathic haemochromatosis and normal red cell ferritin content. We suggest that besides its diagnostic usefulness in untreated patients with suspected idiopathic haemochromatosis the red cell ferritin content may also be used to indicate the effectiveness of phlebotomy in this disease in reducing the erythrocyte ferritin content to that observed in iron deficiency-that is, less than $0.004 \mathrm{fg} / \mathrm{cell} .^{16}$

The mechanism of the raised erythrocyte ferritin content idiopathic haemochromatosis is uncertain. Presumably it reflects molecular mechanisms for iron transport in the nucleated erythrocyte precursor similar to those operating for either the enterocyte or the hepatocyte. An alternative explanation for the high content may be that it is the result of an efficient intracellular influx of iron into marrow cells consequent on the higher degrees of transferrin saturation in the disease. ${ }^{15}$

This study was supported in part by the special research grants of Monash University and the National Health and Medical Research Council of Australia. We thank Dr M Briedahl and the staff of the departments of clinical biochemistry, haematology, and pathology at the Alfred Hospital for help in pathological and biochemical tests; and those physicians, especially Drs S Choong, D Coventry, J Goy, A W Jakobovits, A D McCutcheon, I Roberts-Thomson, J Wettenhall, and $M$ Whiteside and Professor B G Firkin, who referred patients to us.

\section{References}

${ }^{1}$ Halliday JW, Powell LW. Iron overload. Semin Hematol 1982;19:42-53.

${ }^{2}$ Halliday JW, Russo AM, Cowlishaw JJL, Powell LW. Serum ferritin in diagnosis of haemochromatosis. Lancet 1977; ii :621-3.

3 Wands J, Rowe JA, Mezey SE, et al. Normal serum ferritin concentration in precirrhotic hemochromatosis. N Engl F Med 1976;294:302-5.

${ }^{4}$ Simon M, Bourel M, Genetet B, Fauchet R. Idiopathic hemochromatosis. Demonstration of recessive transmission and early detection by family HLA typing. N Engl f Med 1977;297:1017-21.

5 Bomford A, Eddleston AL, Kennedy LA, Batchelor JR, Williams R. Histocompatibility antigens are markers of abnormal iron metabolism in patients with idiopathic haemochromatosis and their relatives. Lancet $1977 ; \mathrm{i}: 327-9$

${ }^{6}$ Bassett ML, Halliday JW, Powell LW, Doran T, Bashir H. Early detection of idiopathic haemochromatosis: relative value of serum ferritin and HLA typing. Lancet 1979;ii:4-7.

7 Jacobs A. Disorders in iron metabolism. In: Hoffbrand AV, ed. Recent advances in haematology. Vol 3. Edinburgh: Churchill Livingstone, 1982: $1-24$.

8 Bassett ML, Halliday JW, Powell LW. Hemachromatosis newer concepts: diagnosis and management. Disease-a-Month 1980;20:1-44.

9 Gioraniello TJ, Di Benedetto G, Palmer DN, Peters T Jr. Fully automated method for the determination of serum iron and total iron binding capacity. In: Automation in analytical chemistry Technicon symposium 1967. Vol 1. White Plains, New York: Mediad, 1968:185-8.

10 Stookey LL. FerroZinc-a new spectrophotometric reagent for iron. Anal Chem 1970;42:779-81.

1 Sternberg JC. A rate nephelometer for measuring specific protein by immunoprecipitin reactions. Clin Chem 1977;23:1456-64.

12 Porter FS. The effect of iron content on the behaviour of ferritin in an inhibition type radioimmunoassay. $\mathcal{F}$ Lab Clin Med 1974;83:147-54.

13 Scheuer PJ, Williams R, Muir AR. Hepatic pathology in relatives of patients with haemochromatosis. Fournal of Pathology and Bacteriology $1962 ; 84: 53-64$

11 Zettner A, Mansbach L. Application of atomic absorption spectrophotometry in the determination of iron in urine. Am f Clin Pathol 1965;44: 517-9.

15 Finch CA, Huebers H. Perspective in iron metabolism. N Englf Med 1982; 306:1520-8.

16 Van Der Weyden MB, Fong H, Hallam L, Briedahl M. A rapid and simple assay for erythrocyte ferritin. Clin Chim Acta (in press).

17 Bomford A, Williams R. Long term results of venesection therapy in idiopathic haemochromatosis. $Q \mathcal{F}$ Med 1976;45:611-23.

18 Powell LW. The role of alcoholism in hepatic iron storage disease. Ann NY Acad Sci 1975;252:124-34.

(Accepted 13 December 1982) 